\title{
Peripheral primitive neuroectodermal tumor
}

INSERM

\section{Source}

INSERM. (1999). Orphanet: an online rare disease and orphan drug data base. Peripheral primitive neuroectodermal tumor. ORPHA:370348

A rare, aggressive, malignant, neoplastic disease characterized by a usually ill-defined, solid, multilobulated mass, frequently having necrosis, located on any site of the body (except the central nervous system), composed of small, round, poorly differentiated cells, with or without Homer-Wright rosettes, showing varying degrees of neuroectodermal differentiation. Manifestations are variable depending on location, with osteolytic destruction being common when arising from bone. 